\title{
The Improvement of Teachers' Professional Competency Through Hots-Based Training
}

\begin{abstract}
Kurnia. F. Astutik ${ }^{1^{*}}$, Erny Roesminingsih ${ }^{2}$
${ }^{1,2}$ Department of Educational Management, State University of Surabaya, Surabaya, Indonesia e-mail: kurnia.19018@mhs.unesa.ac.id ${ }^{1}$, ernyroesminingsih@unesa.ac.id²

Abstract

This study aims to analyze the difference in the average learning outcomes between pre-test and posttest, analyze the effect of HOTS training on teacher professional competence. This research method is quasi-experimental using a quantitative approach. The research sample was 35 elementary school teachers. Data collection in this study using the test method. The design used was one group pre-test post-test design which was analyzed using paired t-test. Hypothesis test results show that there is a difference in the average learning outcomes between the pre-test and post-test, there is a significant effect of HOTS training on the professional competence of teachers. There are still many variables that can be explored to further optimize the formation of policy framework models and theoretical frameworks to improve teacher professional competence.
\end{abstract}

Keywords: Training HOTS, Professional Competence, Teacher

\section{Introduction}

In the era of globalization of competition even harder and strictly accompanied by the emergence of problems that are increasingly complicated and complex, especially in learning to demand increasing teacher professionalism (Mustika, Sutajaya, Negeri, \& Gianyar, 2016). In addition to teacher competencies, 21st-century21st-century competencies in the global era demanding students have critical thinking skills in solving problems, creating creativity, communication and collaboration. The competence is expected to be formed through the process of education in schools, both in the learning process and in the aspects of the assessment carried out by the teacher. According to Law Number 14 of 2005 concerning Teachers and Lecturers explained that the professional competence of a teacher is the ability of teachers regarding the understanding of educational and dialogical learning and learning. (UUGD, 2005).

Learning to process is the process of planning, implementing, and evaluating the learning process through the assessment of learning outcomes. One of the competencies that a teacher must have is the ability to conduct an assessment. (Marsh, 1996). Based on Permendikbud Number 43 of 2019 specifically regulating the assessment held by the school said that the education system must encourage the growth of teaching and learning practices that grow reasonable power and the character of students in full (Sulistiawati, 2019). Law of the Republic of Indonesia Number 20 of 2003 concerning the National Education System Chapter XVI Article $57 \mathrm{Up}$ to 59 concerning Evaluation states that in the context of national education control is evaluated as a form of educational organizers to interested parties. This law stated that evaluations were carried out by independent institutions regularly, overall, transparent, and systematic to assess the achievement of national education standards. The evaluation activity can be carried out properly if evaluation/assessment is carried out professionally and institutionalized. When this assessment is used still has not fostered highlevel thinking skills. This is based on the results of the International Student Assessment (PISA) program to show 62nd from 72 countries. Likewise, the results of the achievements of the trends in the International Mathematics and Science Study (TIMSS) in 2011 showed the score achievement of students reaching 386 of 800 , where the average score was 500 . The situation showed that the achievements of students in Indonesia were below the average. The results of the low PISA and TIMSS studies were caused by most test materials in Pisa and TIMSS which were not in the Indonesian curriculum (Sidharta, 2017). The questions in TIMSS are

\footnotetext{
${ }^{*}$ Corresponding author.

Received 09 December 2020; Accepted 01 February 2021; Available online 01 March 2021

(C) 2020 JPI. All Rights Reserved
}

Jurnal Pendidikan Indonesia (JPI) | 145 
mostly uncovering aspects of reasoning and applications (applying). Students are not familiar with models of questions that use reasoning and logic so that they encourage high-level thinking skills (Higher Order Thinking Skills) (Wicaksono \& Jumanto, 2019). Based on the results of the study, it is necessary to change the system in learning and assessment in the form of AKM (minimum competency assessment).

The assessment system is rolled out by the government in the form of a minimum competency assessment (AKM) which is the assessment of the minimum ability committed to students. The minimum ability in question is the most basic ability that must be possessed by students at a certain level. This basic ability is by the 21 st-century skills demanding students to be able to keep up with the times full of challenges. By mastering the 21st-century skills, students will have learning and innovating skills, skills using and utilizing information technology/media, and can work and survive using life skills. Teachers are expected to be able to compile questions that encourage students to have 21 st-century skills, foster creativity, encourage students in-depth thinking about learning materials that are associated with problem-solving in everyday life (Kusuma, Rosidin, Abdurrahman, \& Suyatna, 2017). The function of the preparation of the matter of hots in the assessment system is an effort to set up the competencies needed in the $21 \mathrm{st}$ century. At present, the development of the world is very rapid so that it requires humans to be able to maintain their lives through various skills musthave. However, in the preparation of HOTS, there are still many teachers who do not understand the characteristics and criteria of HOTS (Armiati et al., 2020).

Quality assessments can improve the quality of education. By training students to answer hots questions expected students to think critically and creatively (Sutarto, 2017). Highlevel thinking skills need to be used in learning in school so that students can be trained to solve difficult problems in their lives. Through these thinking skills, students are expected to find new things and creative and innovative ideas in facing age changes (Widodo \& Indraswati, 2019). Based on the results of supervision of the principal of teachers, most teachers in preparing questions tend to measure low-level thinking skills. The average teacher still has difficulty in preparing questions that can make students creative thinking and measuring highlevel thinking (Kemendikbud, 2017). This indicates that the learning process on educational units has not been held inspiredly, interactive, fun, challenging, and motivating students to actively participate. The implementation of HOTS-based learning evaluations aims for students to be able to think and challenged to develop the reasoning they have (Kusuma et al., 2017).

This study aims to analyze the effect of hots training on teacher professional competencies in terms of preparing quality hots. If the teacher can develop learning evaluations by the competence of the students, the competence of the teacher's professionalism has also increased.

\section{Method}

The method used in this study is quantitative research. The type of research used is the research of pseudo experiments or quasi-experiments. Pseudo experiments are experimental research carried out in one group, namely the experimental group without a control or comparison group. The research design used is One Group Pretest and Posttest Design, namely experimental research carried out in one group selected randomly or randomly. The design of this study was carried out using the pretest measured before treatment and also used the posttest which was measured after treatment thus the results of treatment could be measured accurately (Arikunto, 2013). Data processing method with the SPSS program. Based on the research design above, the analysis used is Paired T-Test. Before the test was carried out, preceded by testing the Validity of the Pre Test and Post Test with the productmoment correlation, and reliability using Cronbach alpha techniques (Wijaya, 2003). If all test requirements have been fulfilled, hypothesis testing is carried out as follows. Ho: There is no difference in the average Pre-Test and Post Test results. Ha: There are differences in the average result of pre-test and post-test. 


\section{Result and Discussion Results}

The data of this study is presented in two conditions, namely learning outcomes before and after attending training as in Table 1 . The results of data analysis on learning outcomes before training are a minimum score of 11.90; a maximum score of 81.67; an average of 36.89; and a standard deviation of 16.382 . The results of data analysis on learning outcomes after attending training are a minimum score of 35.71; a maximum score of 100 ; an average of 77.39 and a standard deviation of 14.92 .

Table 1. Descriptive data

\begin{tabular}{ccccccc}
\hline No & Type & N & Minimum & Maximum & Mean & Std Deviation \\
\hline 1 & Pretest & 35 & 11,90 & 81,67 & 36,8851 & 16,38229 \\
2 & Post-test & 35 & 35,71 & 100,00 & 77,3869 & 14,92444 \\
3 & Valid N (listwise) & 35 & & & & \\
\hline
\end{tabular}

Before the Paired Sample T-test analysis was carried out a prerequisite test in the form of a normality test. Based on the SPSS output of the Kolmogorov Smirnov test in Table 2, the significance value for the Pretest and Posttest data is greater than $0.05(0.200>0.05)$.

Table 2. Normality test

\begin{tabular}{cccccccc}
\hline & \multicolumn{4}{c}{ Kolmogorov-Smirnov } & \multicolumn{3}{c}{ Shapiro-Wilk } \\
\cline { 2 - 7 } No & Type & Statistic & Df & Sig. & Statistic & df & Sig \\
\hline 1 & Pretest & 0,074 & 35 & 0,200 & 0,961 & 35 & 0,253 \\
2 & Post-test & 0,116 & 35 & 0,200 & 0,934 & 35 & 0,037 \\
\hline
\end{tabular}

Based on the results of the Paired-Samples T-test in Figure 3 using a significance level of 0.05 it can be seen that the significance value obtained is $0.000<0.05$

Tabel 3. Paired Samples t-Test

\begin{tabular}{|c|c|c|c|c|c|c|c|c|c|}
\hline \multirow[b]{3}{*}{ No } & \multicolumn{9}{|c|}{$\begin{array}{l}\text { Paired Differences } \\
\end{array}$} \\
\hline & & & $95 \%$ & onfidence & terval of & he Differ & nce & & \\
\hline & & $\begin{array}{c}\text { Mea } \\
n\end{array}$ & $\begin{array}{c}\text { Std. } \\
\text { Deviation }\end{array}$ & $\begin{array}{l}\text { Std Error } \\
\text { Mean }\end{array}$ & Lower & Upper & $\mathbf{t}$ & Df & $\begin{array}{l}\text { Sig. (2- } \\
\text { tailed) }\end{array}$ \\
\hline 1 & $\begin{array}{l}\text { Pre } \\
\text { Test }\end{array}$ & $\begin{array}{c}- \\
40,5 \\
01\end{array}$ & 17,205 & 2,908 & $-46,412$ & $-34,592$ & $-13,927$ & 34 & 0,00 \\
\hline 2 & $\begin{array}{l}\text { Post } \\
\text {-test }\end{array}$ & & & & & & & & \\
\hline
\end{tabular}

\section{Discussion}

Based on the results of the calculation of the construct validity carried out at the level of 0.05 for the Pretest and Posttest instruments have obtained 7 valid items and 1 other item are invalid. While the reliability test at the level of 0.05 obtained by Alpha Chronbach's value 0.533 indicates consistent instrument readability. Table 1 showed an increase in the pretest and posttest average results from 36.8851 to 77.3869 . An increase of 40.5018 shows a better understanding of teachers after attending hots. After being given training and tests, the average mastery of teachers in preparing the Problem of HOTS has increased with the smallest post-test deviation compared to the time before treatment. This indicates data distribution is more centered at the central point compared to the previous treatment. These results are in line with the research conducted by Hafiyush that mentoring and training will improve the ability to compile hots (Hafiyusholeh et al., 2020).

Before the Paired Sample T-test analysis was carried out a prerequisite test in the form of a normality test. Based on the SPSS output of the Kolmogorov Smirnov test in Table 2, the 
significance value for the Pretest data is greater than $0.05(0.200>0.05)$ so it can be concluded that the pretest data is normally distributed. Likewise for the posttest data significance value greater than $0.05(0.200>0.05)$ so it can be concluded that the posttest data is normally distributed. Thus the requirements or assumptions of normality in the use of the Paired Sample T-test have been fulfilled.

Analysis of Paired Sample T-Test is used to test the hypothesis of whether there are differences in learning outcomes between before and after attending hots training. The results of the paired sample t-test are displayed in Table 3. Based on the results of the paired-samples $\mathrm{t}$-test using the 0.05 significance level can be seen that the significance value obtained is 0,000 $<0.05$. So Ho is rejected and $\mathrm{Ha}$ is accepted (Gunawan, 2016). Thus it can be concluded that there are significant differences in learning outcomes between before and after attending hots training. This was supported by the average increase in learning outcomes before attending hots training of 36.89 to 77.39 after attending hots training. There was a significant increase in a significant score before and after participating in hots training of 40.5 .

This training is intended to provide provision of knowledge and insight into various learning innovations both conceptual and practice in the framework of increasing teacher professionalism and the acquisition of learning outcomes of students (Haryono, Stanislaus \& Widhanarto, 2017). Training is one way to develop human resources. One of the most effective methods that can and must be used by institutions to develop human resources in these institutions through the provision of education and training. This education and training aim to improve technical, theoretical, and conceptual capabilities so that educators can achieve optimal performance. Education and training have a systematic change from knowledge, skills, attitude, and behavior which continues to increase so that it can realize the targets to be achieved by the institution to meet the desired human resource standards (Samsudin, 2006).

The teacher is a key human resource in improving the quality of education, and teachers here are in a very strategic position for all educational reform efforts that are oriented towards achieving the quality of students and schools. The efforts made in improving the quality of education in a school system will become meaningless if not accompanied by the existence of professional teachers (Putri \& Nugroho, 2016) and (Nurhajati \& Bachri, 2018). In general, the success of a business is closely related to the quality of people who do the business. This also applies to the success of the school determined by the success of its leadership in managing educators and existing education personnel so that they become professional energy (Yasin, 2011). One of the demands of professional educators is an educator who acts as an evaluator (Darmadi, 2015). The purpose of the evaluator is to have the ability to conduct evaluations and assessments so that the training of the preparation of this HOTS problem is used to improve teacher capabilities in aspects of learning assessment (Helmi, 2015).

Assessment with the matter of HOTS is also able to develop thinking skills. Thinking skills are a combination of two words that have different meanings, namely (thinking) and skills (skills). Thinking is a cognitive process while skills are actions from collecting and selecting information, analyzing, drawing conclusions, ideas, problem-solving, evaluating choices, making decisions, and reflecting (Wilson, 2000). Category Hots according to (King, Goodson, \& Rohani, 1998) are as follows: (1) think critically and logical thinking, (2) reflective thinking, (3) thought metacognitive, and (4) creative thinking. Not different from Zohar and Dori who categorize hots into: (1) constructive arguments, (2) asking scientific questions, (3) making comparisons, (4) solving complicated non algorithm problems, (5) classify the difference between opinions, and (6) identify implied assumptions (Zohar \& Dori, 2003). In general, the matter of hots measures the metacognitive dimensions, namely the ability to connect several different concepts, interpret and solve problems and make decisions from difficult problems (Kurniati, Harimukti, \& Jamil, 2016). The characteristics of HOTS are as follows (1) measuring high-level thinking skills, (2) based on contextual problems, (3) not routine (not familiar), (4) using various forms of questions (Kemendikbud, 2017)

The Ministry of Education and Culture classifies the cognitive level to 3 namely (1) knowledge and understanding, (2) application, (3) reasoning. Cognitive levels of knowledge and understanding (level 1) measure factual, conceptual, and procedural knowledge. The 
operational verb used is: mention, distinguish, explain, register, count, and others. Cognitive Application Levels (Level 2) Measuring Capability: a) Using certain factual, conceptual, and procedural knowledge in other concepts, b) use certain, conceptual, and procedural knowledge to solve contextual problems with different situations. The cognitive level of reasoning (level 3) at this level measures the ability to analyze, evaluate and create. Of the three levels described above which includes the HOTS level (Higher Order Thinking Skills) is at the cognitive level of reasoning (level 3), for the application cognitive level (level 2) entered the MOs (middle-order thinking skills) while the level of cognitive knowledge and understanding Including lots levels (Lower Order Thinking Skills). Whereas according to Anderson \& Krathwohl classify the dimensions of the process of thinking as follows (Anderson \& Krathwohl, 2001):

Table 4. The dimensions of the thought process

\begin{tabular}{ccc}
\hline Cognitive level & & Dimensions of operational verbs \\
\hline HOTS & Create & Create your ideas \\
& Evaluate & Make your own decision \\
& Analysis & Specify aspects / elements \\
MOTS & Apply & Use info on different domains \\
& Understanding & Explain the idea/concept \\
LOTS & Knowing & Recalling \\
\hline
\end{tabular}

Presentation of hots questions in assessment can train students to improve their abilities and skills by the demands of 21 st-century competencies (Mahfuzah \& Utomo, 2018). Through the 21st century, hots-based assessment can be built through training activities to resolve various real problems in everyday life. Students can feel that the subject matter obtained in the class is useful and can be used as a provision to plunge into the community (Kemendikbud, 2017). The ability of students to think high levels reach more than $50 \%$, even though there are still students who are not right in answering the problem of hots. By the GAIS statement that several factors caused students who are not right in resolving the problem of hots, namely the minority, not optimal the learning process, lack of understanding of the question, incompleteness in reading questions so that hots-based assessments must continue to be presented (Gais \& Aldila, 2017).

Based on the results of interviews with teachers it was found that most of the students were at the level of thinking analysis. Dimensions measure the ability of students in specifying aspects/elements, deciphering, organizing, comparing, and finding implied meaning (Kemendikbud, 2017). According to Anderson, the dimensions of thinking analysis are the ability to think that breaks the material into parts so that the organizational structure of the material can be understood. Students who have achieved the ability of thinking analysis can connect material between parts into one unit structure (Anderson \& Krathwohl, 2001). Students who achieve cognitive levels of evaluation dimensions can make considerations based on criteria or standards, compiling hypotheses, criticizing, predicting, assessing, testing, justifying, and blaming. Students who achieve the cognitive level of creating dimensions can place elements together to form a coherent or functional overall and reorganize the elements into a new pattern or structure (Kemendikbud, 2017).

The results of this study are in line with the results of (Handayani \& Amirullah, 2019), (Samo \& Garak, 2020), (Sari, Cahyaningtyas, Maharani, Yustiana, \& Kusumadewi, 2019) and (Rintayati, Istiyati, \& Syawaludin, 2020) Which states that the existence of training provides opportunities and space for teachers to improve teacher's readiness and understanding in carrying out the learning and assessment of hots-based. The results of the T-test analysis provide information that training has a positive impact to improve the ability of teachers in preparing hots-based assessments. The quality of learning can be done by increasing teacher competencies and the curriculum will not be significant if it is not supported by the ability of the teacher in implementing the curriculum. 


\section{Conclusions and Suggestions}

Primary school teacher training in the context of increasing teacher professional competencies through Mastery of HOTS (Higher Order Thinking Skills) produces several conclusions including the ability of elementary school teachers in resolving the Thinking Skills (HOTS) high-order questions experiencing a significant increase. The implementation of the Teacher Professional Competency Increasing Program is carried out through training in designing and resolving the Thinking High Order Questions which are then assisted. The training program has a positive effect on the increase in teacher capabilities as well as its implementation in classroom learning activities.

\section{Acknowledgment}

We would like to express my gratitude to the Dean of Education Faculty, Universitas Negeri Surabaya who supports funding for this research

\section{References}

Anderson, L., \& Krathwohl, D. (2001). A Taxonomy of Learning Teaching, and Assessing: A revision of Bloom's Taxonomy of Educational Objectives. Longman.

Arikunto, S. (2013). Prosedur Penelitian: Suatu Pendekatan Praktik. Rineka Cipta.

Ariyana, Y., Pudjiastuti, A., Bestari, R., \& Zamroni. (2018). Buku Pegangan Pembelajaran Berorientasi pada Keterampilan Berpikir Tingkat Tinggi. Direktorat Jenderal Guru dan Tenaga Kependidikan Kementerian Pendidikan dan Kebudayaan.

Armiati, Subhan, M., Nasution, M. L., Aziz, S. Al, Rani, M. M., Rifandi, R., \& Harisman, Y. (2020). Profesionalisme guru dalam membuat soal higher order thinking skills. JNPM $\begin{array}{llll}\text { (Jurnal Nasional Pendidikan Matematika), } & 4(1), & \end{array}$ https://doi.org/10.33603/jnpm.v4i1.2587.

Darmadi, H. (2015). Tugas, Peran, Kompetensi, dan Tanggung Jawab Menjadi Guru Profesional. Pendidikan, 13, 163-164. Retrieved from https://journal.ikippgriptk.ac.id/index.php/edukasi/article/view/113.

Gais, Z., \& Afriansyah, E. A. (2017). Analisis kemampuan siswa dalam menyelesaikan soal high order thinking ditinjau dari kemampuan awal matematis siswa. Mosharafa: Jurnal Pendidikan Matematika, 6(2), 255-266. https://doi.org/10.31980/mosharafa.v6i2.313.

Gunawan, I. (2016). Pengantar Statistika Inferensial. Rajawali Pers.

Hafiyusholeh, M., Lubab, A., Asyhar, A. H., Fanani, A., Farida, Y., Novitasari, D. C. R., ... Hamid, A. (2020). Pendampingan Guru Madrasah untuk Mewujudkan Kompetensi Pedagogik Guru Matematika yang Berdaya Melalui Penguasaan Soal High Order Thinking Skills (HOTS). Engagement: Jurnal Pengabdian Kepada Masyarakat, 4(1), 183-200. https://doi.org/10.29062/engagement.v4i1.97.

Handayani, S. L., \& Amirullah, G. (2019). Meningkatkan pemahaman guru Sekolah Dasar melalui pelatihan penyusunan Rencana Pelaksanaan Pembelajaran berbasis literasi, 4C, PPK dan HOTS. Jurnal SOLMA, 8(1), 14. https://doi.org/10.29405/solma.v8i1.2949.

Haryono, H., Stanislaus, S., Budiyono, B., \& Widhanarto, G. P. (2017). Peningkatan Profesionalisme Guru melalui Pelatihan Inovasi Pembelajaran: Program Rintisan bagi Guru di Kabupaten Semarang. Lembaran IImu Kependidikan, 46(2), 75-80. https://journal.unnes.ac.id/nju/index.php/LIK/article/view/12031.

Helmi, J. (2015). Kompetensi profesionalisme guru. Al-Ishlah Jurnal Pendidikan, 7(2), 319336. https://doi.org/10.35445/alishlah.v7i2.43.

Kemendikbud. (2017). Modul Penyusunan Soal Higher Order Thinking Skill (HOTS). Direktorat Pembinaan SMA Ditjen Pendidikan dasar dan Menengah.

King, F. J., Goodson, L., \& Rohani, F. (1989). Assessment And Evaluation Higher Order Thinking Skills. A Publication Of The Educational Service Program. http://www.cala.fsu.edu/files/higher_order_thinking_skills.pdf.

Kurniati, D., Harimukti, R., \& Jamil, N. A. (2016). Kemampuan berpikir tingkat tinggi siswa SMP di Kabupaten Jember dalam menyelesaikan soal berstandar PISA. Jurnal Penelitian Dan Evaluasi Pendidikan, 20(2), 142-155. https://doi.org/10.21831/pep.v20i2.8058. 
Kusuma, M. D., Rosidin, U., Abdurrahman, A., \& Suyatna, A. (2017). The Development of Higher Order Thinking Skill (Hots) Instrument Assessment In Physics Study. IOSR Journal of Research \& Method in Education (IOSRJRME), 07(01), 26-32. https://doi.org/10.9790/7388-0701052632.

Mahfuzah, B. A., Munzil, M., \& Utomo, Y. (2018). Efektivitas GDL (Guided Discovery Learning) dan Problem Solving terhadap KBK (Keterampilan Berpikir Kritis) dan HOTS (Higher Order Thingking Skills). Jurnal Pendidikan: Teori, Penelitian, Dan Pengembangan, 3(6), 739-744. http://dx.doi.org/10.17977/jptpp.v3i6.11131.

Marsh, C. (1996). Handbook for Beginning Teachers. Addison Wesley Longman Australia Pry Limited.

Mustika, P. W. \& Sutajaya, (2016). Ergonomi dalam pembelajaran menunjang profesionalisme guru di era global. JPI (Jurnal Pendidikan Indonesia), 5(1), 82-96. http://dx.doi.org/10.23887/jpi-undiksha.v5i1.8933.

Nurhajati, W. A., \& Bachri, B. S. (2018). Pengembangan Kurikulum Diklat (Pendidikan dan Pelatihan) Berbasis Kompetensi dalam Membangun Profesionalisme dan Kompetensi Pegawai Negeri Sipil (PNS). Jurnal Pendidikan (Teori Dan Praktik), 2(2), 156. https://doi.org/10.26740/jp.v2n2.p156-164.

Putri, W. N., \& Nugroho, M. A. (2016). Strategi Pengembangan Profesionalisme Tenaga Pendidik di Madrasah. MUDARRISA: Jurnal Kajian Pendidikan Islam, 8(2), 313. https://doi.org/10.18326/mdr.v8i2.313-340.

Rintayati, P., Istiyati, S., \& Syawaludin, A. (2020). Peningkatan kemampuan guru Sekolah Dasar dalam Merancang Pembelajaran IImu Pengetahuan Alam Berkategori HOTS melalui pelatihan partisipatif. Jurnal Pendidikan Dasar Nusantara, 5, 202-210. https://doi.org/10.29407/jpdn.v5i2.13543.

Samo, D. D., \& Garak, S. S. (2020). Pelatihan pengembangan soal geometri level Higher Order Thinking Skill (HOTS) bagi guru Sekolah Dasar di Kota Kupang. Pengabdian Masyarakat IImu Keguruan Dan Pendidikan, 17-27. https://doi.org/10.31326/jmpikp.v2i01.260.

Samsudin, S. (2006). Manajemen Sumber Daya Manusia. PT Pustaka Setia.

Sari, Y., Cahyaningtyas, A. P., Maharani, M. M., Yustiana, S., \& Kusumadewi, R. F. (2019). Meningkatkan kemampuan menyusun soal IPA berorientasi HOTS bagi guru Sekolah Dasar Gugus Pandanaran Dabin IV UPTD Semarang Tengah. Indonesian Journal of Community Services, 1(2), 175-183. http://dx.doi.org/10.30659/ijocs.1.2.175-183.

Sulistiawati. (2019). Peningkatan kemampuan penyelesaian soal ujian nasional berorientasi higher order thinking skills(HOTS) melalui pelatihan pengembangan soal HOTS bagi guru Matematika SMP. (2009), 180-189.

Sutarto, M. (2017). Articulation of High Order Thinking Skills in Competency-Based Instruction in Indonesia Vocational and Technical High School. 102(Ictvt), 211-217. https://doi.org/10.2991/ictvt-17.2017.36.

UUGD. (2005). Undang-Undang RI No 14 Tahun 2005 Tentang Guru dan Dosen.

Wicaksono, A. G., \& Jumanto, J. (2019). Pengembangan Soal Higher Order Thinking Skills (Hots) Bagi Guru Sekolah Dasar. Adi Widya: Jurnal Pengabdian Masyarakat, 3(2), $14-$ 20. http://dx.doi.org/10.33061/awpm.v3i2.3352.

Widodo, A., \& Indraswati, D. (2019). Analisis Konten Hots Dalam Buku Siswa Kelas V Tema 6 (panas Dan Perpindahannya) Kurikulum 2013. Madrasah: Jurnal Pendidikan Dan Pembelajaran Dasar, 12(1), 1-13. https://doi.org/10.18860/mad.v12i1.7744.

Wijaya. (2003). Statistika Non Parametrik. Tarsito.

Wilson, V. (2000). Educational forum on teaching thinking skills. Scottish Executive Education Department. http://www.sciesocialcareonline.org.uk

Yasin, A. (2011). Pengembangan Sumber Daya Manusia di Lembaga Pendidikan Islam. UIN Maliki Press.

Zohar, A., \& Dori, Y. J. (2003). Higher order thinking skills and low-achieving students: Are they mutually exclusive?. The journal of the learning sciences, 12(2), 145-181. https://doi.org/10.1207/S15327809JLS1202_1. 